\title{
Defense Education Enhancement Program: The Consortium Perspective
}

\author{
John Berry *
}

\section{The Early Years}

The Partnership for Peace Consortium of Defense Academies and Security Studies Institutes, based at the George C. Marshall Center in Garmisch, Germany, is leading an innovative and unprecedented program for defense education reform in five Partner countries (Armenia, Azerbaijan, Georgia, Kazakhstan, and Moldova). The modus operandi for these efforts includes finding fertile ground for defense reform in other countries beyond the Partnership for Peace nations. Defense education in general is gaining attention as a useful tool for security policy makers. Why and how this is happening is an intriguing story that begs to be told. This article attempts to tell that story.

It begins, as do so many post-Cold War accounts, with the demise of the Warsaw Pact and the USSR in 1991 and the steadily growing interest from Central and Eastern European countries in NATO membership. At the same time, the newly independent sovereign states of the USSR, the former Soviet Socialist Republics, began to choose their own paths. Some of them installed democratic systems of government and links to the West, while others retained authoritarian rulers.

NATO's response to all three groups began first as an offer of a "hand of friendship," an exploration of a new cooperative relationship. By 1994, this hand evolved into the Partnership for Peace, a practical program of bilateral cooperation for those states willing to participate as Partners alongside NATO Allies. NATO shaped these individual programs initially around achieving interoperability for peacekeeping operations, a useful goal indeed as a number of Partner countries deployed troops to Bosnia and Herzegovina in 1996. By 1999, NATO opened its doors to three new members, a political choice based heavily on military criteria - specifically, on what these countries could add to the Alliance's capabilities.

In the same year, NATO endorsed the Partnership for Peace Consortium, a joint German-American initiative established to strengthen defense and military education and research through international cooperation. Switzerland and Austria quickly joined the Consortium as stakeholders. NATO remained on the sidelines, preferring to see the organization operate "in the spirit of PfP," free to follow the interests of the stakeholders and the Partner members.

John Berry is the Chair of the Education Development Working Group (ED WG) of the Partnership for Peace Consortium. He has been closely associated with the Consortium since his retirement as Dean of the NATO Defense College in 2005. In that position, he saw first hand the great need to help partner countries, and in particular partner defense educators, set aside their legacy systems of defense education through peer-to-peer associations with their Euro-Atlantic counterparts. The work of the ED WG is devoted to that end. 


\section{Uncharted Territory}

The Consortium embarked on a journey of discovery into uncharted territory, helping the Partners find their way in security sector and defense education reform. Switzerland's Center for the Democratic Control of Armed Forces played a key role in these early years. Working groups in fields of interest to both the stakeholders and the Partners formed, met, and exchanged ideas. Although exposure to Western colleagues was valuable, a number of working groups drew criticism because they lacked "products" or "deliverables," as some like to call them. ${ }^{1}$

A new vista opened for the Consortium with the publication of NATO's Partnership Action Plan for Defense Institution Building (PAP-DIB) and its supporting initiative for Education for Defense Reform in 2004-05. Soon after, NATO's International Staff saw promise in the Consortium as a way to influence defense institution building in Partner states and joined the Consortium as a stakeholder. But what concrete tasks should the Consortium take on? How and where should it start?

\section{New Energy, New Directions}

An intriguing idea emerged in early 2006. An ad hoc group of defense educators, calling themselves the "Friends of PAP-DIB," met several times that year and elaborated what eventually became the foundation for the current Defense Education Enhancement Programs, or DEEPs. The formula was simple in concept - to engage Western defense educators in peer-to-peer discussions with their Partner counterparts on three themes:

- What to Teach (that is, curriculum content)

- How to Teach and Learn (pedagogy)

- Faculty Development (peer-to-peer mentoring aimed at a holistic approach to defense education).

This framework became the charter for one of the Consortium's original working groups, Curriculum Development, which was appropriately renamed the Education Development Working Group, or ED WG.

In the same time frame, in 2007 the U.S. Office of the Secretary of Defense, the major source of funds for the Consortium, called on the organization for concrete action plans to support its new policy of "Building Partner Capacity." This call came with an implicit warning: future funding depended on results.

There is nothing quite like a threat to a vital source of funds to inspire creativity. And that is what happened. The Chair of the ED WG and the Executive Secretary of the Consortium coined the phrase "Defense Education Enhancement Program," and set out the initial framework for the program, proposing as the aim "To contribute to the professionalization of the officer corps and civilian defense officials of Partner nations through

1 Switzerland's Security Sector Reform Working Group and Advanced Distributed Learning Group and Austria's Balkans Study Group were notable exceptions. 
improved curriculum and learning methods, faculty and institution development and holistic professional military education through sustained engagement over time."

\section{Launching the DEEPs}

Each DEEP would be led by a senior defense educator, a volunteer who would only be compensated for his or her travel expenses. The DEEP would be tailored to the expressed needs of a Partner country, with an initial three-year time horizon. NATO International Staff would play a leading role in determining those needs in broad strokes, through the vehicle of the Partner state's Individual Partnership Action Plan. This topdown authority of the IPAP, a co-signed official document, meant that the expertise of the DEEP leader would be met with open doors on first contact. It meant also that their counterparts, senior defense educators in the Partner nation, had a mandate from above for change, no small matter in countries unfamiliar with bottom-up change.

Kazakhstan was selected as the place to test all these ideas. With strong support from both the United States Central Command and the Office of the Secretary of Defense, the Consortium launched its first pilot DEEP with Kazakhstan's National Defense University (NDU) in late 2007. Most of the "rules of the road" for future DEEPs were developed in this pilot project. The first step was the selection of the program leader, Dr. Al Stolberg of the U.S. Army War College. Familiar with planning and implementing security cooperation programs in many nations in Europe and Eurasia as part of his assignments to the Joint Staff and United States European Command, Dr. Stolberg's position on the teaching faculty of the War College made him a natural choice to lead the DEEP.

\section{Three Cups of Tea}

A metaphor that shaped the approach to this first DEEP was a book that was widely read at that time, Three Cups of Tea by Greg Mortenson. Dr. Stolberg considered his first trip to Schuchinsk in late 2007 his first cup of tea, a chance to meet and establish a relationship with the Ministry of Defense leadership and the faculty of the Kazakh National Defense University. A draft action plan emerged, with Dr. Stolberg taking the lead on the first item, a lecture and faculty mentoring session on the teaching of national security strategy (the second cup of tea). Other engagements followed on topics of interest to the Kazakh faculty.

The third cup of tea, metaphorically, came with one of those engagements: the dispatch of a faculty team on learner-centered teaching, the polar opposite of traditional faculty-centered teaching so prevalent in the Soviet system. The NDU's leadership and faculty connected to this new approach and experimented with it. By the time Dr. Stolberg returned to Kazakhstan for the first annual review of the DEEP, eighteen months after his first visit, the faculty proudly told him they had introduced the new learning methods in many of their courses. Dr. Stolberg describes in greater detail elsewhere in this issue the journey of the Kazakh DEEP.

As was seen in the pilot example in Kazakhstan, the confidence building that follows from these multiple "cups of tea" (conversations, really) can help tap into and stimulate pent-up desire for reform in the Partner nation. The DEEPs have shown military and 
government officials in the host country a possible way to achieve reforms, one that leaves them the flexibility to make their own choices.

This initial success in Kazakhstan provided the essential confidence for the Consortium to launch other DEEPs in 2008. NATO played a key role at this point. Working informally with the NATO Missions of Georgia, Azerbaijan, and Armenia, and using the mechanism of the Individual Partnership Action Plan (IPAP), NATO's International Staff urged these countries to add defense education to their IPAP goals. In quick succession, a senior MOD official from these countries asked a senior NATO official, usually at the Assistant Secretary-General level, to open a dialogue on potential education reforms. Unprompted, Moldova asked for its own DEEP in early 2009 in a letter from its President to NATO's Secretary-General. The Kazakh DEEP had opened the door to launch these additional programs.

\section{The DEEP in Action}

\section{Who Does the Work?}

It is useful here to reflect on why experienced Western academics would even consider joining a DEEP team. Apart from the fact that active duty personnel everywhere are generally not allowed to accept compensation beyond their normal salary, why volunteer at all? The answer varies from person to person, but most often lies somewhere among the following list of considerations: the opportunity for professional development; a new professional challenge; a break from one's routine; a chance to travel; and, most telling, the possibility to help fellow educators and their native countries to shed their Cold War legacy. Some marvelous educators (and not just from the U.S., it is important to say) have stepped forward to offer their time and expertise.

One additional ingredient is needed. Even if they are volunteers, even if their expenses are fully covered by the Consortium and NATO instead of being charged to their home institution, what about the time away from their normal duties? In short, why would supervisors support the periodic absences of their personnel? A lucky break in relying on defense educators for the DEEPs is that they teach in cycles. Between these cycles, many academics have short periods of downtime, and thus have the flexibility to travel. Particularly if their time away from their home institution is short and involves professional development, many supervisors will support academics in taking advantage of such opportunities. With careful juggling of schedules, both on the part of the DEEP volunteers and the Partner's academic calendar, the DEEP action plans move forward.

It is a remarkable feature of the DEEPs that the work is done by volunteers, is supported by volunteer institutions, and is endorsed by volunteer nations. While the United States provides the bulk of the funds and the defense educators and does much to shape the content of the DEEPs, it is by no means alone. NATO's contributions through the influence of the IPAP, the public recognition NATO gives to both defense education reforms in Partner countries and the support provided by Allies, its coordinating role in scheduling events and recruiting educators from NATO nations, and those talented educators themselves all converge to enable the program to advance. Switzerland, Austria, 
Canada, Poland, Hungary, the Czech Republic, Romania, Lithuania, Latvia, Estonia, and the Netherlands have been among the contributing nations.

\section{Who Pays?}

One other vital step was needed in launching the DEEP model. The unavoidable question-Who is going to pay for all this? - required an answer. Here the credit goes to the U.S. Office of the Secretary of Defense, which was willing to commit funds from an account created in the mid-1990s called the Warsaw Initiative Fund (WIF). This account, conceived in 1994 and proposed by President Clinton in a speech in Warsaw, sets aside funds annually to support countries that were members of NATO's Partnership for Peace.

In this case, the PfP Consortium staff pressed successfully for a modest share of the WIF account, enough to cover the travel expenses of Partner educators, U.S. educators, and, in a few cases, NATO educators to participate in the events on the DEEP action plans. While it is never easy to insert a new budget item into the robust budget-planning process, OSD recognized the potential contribution of the DEEPs to two OSD policies regarding the Partner countries, Building Partner Capacity and Defense Institution Building.

It helped significantly in this critical step that no stipends for the time and expertise of these individuals were included. The Consortium asked only for plane fare and daily allowances. The entire annual budget for the DEEPs and its related programs (described below) came to roughly USD 500,000, a rounding error in the multi-billion dollar U.S. defense budget.

Success attracts new contributors, and NATO stepped in decisively with its own funds, focusing primarily on the corps of European defense educators willing to contribute their time and expertise. NATO has also supported Partner travel, and has occasionally even helped fund travel by a needed U.S. educator who had not been planned for in the annual budget. As for the Partner nations themselves, they do not have the funds for many of these educational initiatives. In almost every case the Partners are generous with in-kind contributions associated with hosting events and visitors.

\section{Reference Curricula}

The in-country events conducted under the rubric of the DEEP are not the sum total of the program. Two other elements of defense education enhancement contribute significantly and directly to the goals raised earlier: What to Teach and How to Teach and Learn.

The Partner countries emerged from the breakup of the USSR with few defense education institutions of their own. The course content they knew was heavily Soviet and then Russian-inspired. The Consortium understood early in the DEEP project that the development of skills in writing proper curricula, with goals and objectives based on accepted instructional design principles, was an area that needed attention. Mentoring in particular academic disciplines and course content areas would also benefit Partner fac- 
ulties. Good curricula would also contribute to understanding the holistic nature of professional military education, the hierarchy of schools that lead from Cadet to Colonel.

The Canadian Defence Academy (CDA), working within the framework of the Consortium, led the way to meet these challenges. NATO's Partnership Action Plan for Defense Institution Building (PAP-DIB) provided the ideal starting point. Dr. David Emelifeonwu of the CDA led a multinational team of educators from Allied and Partner states to draft a Reference Curriculum for Defense Institution Building, the first multinational collaborative effort of its kind on behalf of Partner defense education. The term "Reference Curriculum" carries special meaning in this context. It is offered to Partners not as an exact prescription to be adopted wholesale but rather as a set of generic suggestions to consider in drafting their own course content, drawing on the methods in curriculum development they see in the document.

Another Reference Curriculum followed two years later, an ambitious effort centered on generic Officer Professional Military Education. A third effort is currently under way, on Non-Commissioned Officer Professional Military Education, with publication anticipated for October of 2013. NATO has played a vital role by publishing these curricula, publicizing and circulating them throughout all NATO missions, and joining the Consortium in placing them on their websites.

\section{Learner-Centered Pedagogy}

The third pillar of the DEEP, and perhaps its most challenging, is the eternal question of "How to Learn." "How to Teach" is an alternate expression of the task, but educators generally prefer to put the focus on student learning outcomes versus faculty input and teaching. For centuries, higher-level military schools have relied on students' passive learning of lectures given by respected senior officers and educators. Some of the more enlightened institutions use question and answer sessions, but do not include any forum in which the authority on the podium might be challenged. This was largely the system that was in place when U.S. and NATO educators first began working with their Partner counterparts through the DEEPs.

Sensing the opportunity to influence learning outcomes in Partner states, the Consortium turned first to the U.S. Naval Postgraduate School to form a multinational team of educators experienced in pedagogy. The Consortium then asked the Partners to select their own defense educators for a three-day workshop to "explore and develop resourceful learning and teaching approaches." The Consortium has repeated this multinational workshop each year since its inception in 2007, touching well over 150 Partner educators.

Under the guiding hand of Dr. Kathaleen Reid-Martinez, the scope of the annual event has broadened over time to where, in the most recent workshop hosted by Armenia, the goal is now "to reflect together on methods of learning, teaching, and assessment that support educational initiatives based on better insight and best practices from the experience of all." The aim is a growing cohort of Partner defense educators who are willing and able to introduce change in their schools and colleges. It is worth noting that 
this shift to learner-centric models is happening in the West as well, where it is also relatively new and challenging.

\section{Does it Matter?}

My conclusion is that Yes, these programs do matter. The Partners have demonstrated progress at each annual review and have asked to continue their DEEPs beyond the initial three-year horizon. In every country, they have added new levels of professional military education. All now have instituted, or will soon, a senior command and staff college. Kazakhstan has introduced a war college, and others have one under study. Course structures and content increasingly reflect the influence of this contact with the West that the DEEPs have brought. New learning methods are in place, replacing alllecture/rote learning methods with seminars and faculty-student interaction. These changes are still fragile, subject to budget cutbacks and personnel turnover. But they are real. Clearly, the Partners have done much of this work themselves, but the peer-to-peer approach of the DEEPs means that Western colleagues are walking the path together with them, helping, suggesting, and mentoring along the way.

In conclusion, the DEEPs are demand-driven, not supply-driven. Action plans are built around expressed Partner needs, but with the benefit of exposure to Western defense educators they are free to suggest new approaches. Educators who volunteer their time lead the DEEP teams, rather than action officers on assignment. Their PME institutions endorse their participation. Travel and per diem expenses are kept reasonable, and are paid by the U.S. and NATO, presenting no cost to the Partner institutions. The Consortium and NATO IS provide vital administrative support to the volunteers, without which the volunteer pool would quickly dry up. The Consortium works in close and productive partnership with NATO, where each Partner nation's Individual Partnership Action Plan provides top-down direction for the commitment to change. There is equally close and mutually reinforcing collaboration with the U.S. Office of the Secretary of Defense. Warsaw Initiative Funds are the financial heart of the DEEPs.

One other indicator of success is the appearance of NATO-inspired DEEPs outside the geographical limits of the Partnership for Peace. Though in their early stages, DEEP action plans for Mauritania (a Mediterranean Dialogue country) and for Iraq and Afghanistan are taking form. These future prospects are promising, but it all began with the pioneering work of the PfP Consortium well over a decade ago. 